\title{
Krzysztof Krysieniel
}

\section{Między Dayton a Brukselą. Perspektywy transformacji polityczno-ustrojowej w Bośni i Hercegowinie}

Parafowane przed piętnastu laty w bazie wojskowej Wright-Patterson w Dayton ${ }^{1}$ porozumienie ${ }^{2}$ z jednej strony zakończyło najkrwawszy od zakończenia II wojny światowej konflikt zbrojny w Europie, z drugiej miało stać się podstawa dla funkcjonowania w warunkach pokojowych tego niezwykle głęboko podzielonego państwa. Trwająca trzy i pół roku wojna przyniosła ponad 100 tys. ofiar śmiertelnych, „czystki etniczne” na masową skalę, emigrację setek tysięcy obywateli oraz niewyobrażalne straty materialne. Jej skutkiem była również konieczność zbudowania zupełnie nowego systemu politycznego, stworzenie niemal od podstaw ustroju, który mógłby zostać zaakceptowany przez wszystkie strony konfliktu - Bośniaków, Serbów i Chorwatów. Zatem zadania, które postawiono przed uczestnikami obrad, były niezwykle poważne ${ }^{3}$. Czy zostały jednak wykonane, a jeśli tak, to czy w pełni?

Patrząc z perspektywy czasu, który minął od listopada 1995 r., można stwierdzić, że cele postawione w Dayton spełniono połowicznie. O ile bez wątpienia porozumienie przyczyniło się do powstrzymania dalszych walk, to już model zaproponowany przy stole rokowań okazał się $\mathrm{w}$ wysokim stopniu niefunkcjonalny, a przy tym bardzo kosztowny. Bośnia i Hercegowina (BiH) istnieje $\mathrm{w}$ dużej mierze dzięki pomocy finansowej $\mathrm{z}$ zewnątrz, a zaproponowane rozwiązania dotyczace systemu społeczno-politycznego zamiast budować jedność państwa, doprowadziły de facto do paraliżu jego instytucji. Ich niemoc spowodo-

${ }^{1}$ Oficjalne podpisanie porozumienia odbyło się w Paryżu trzy tygodnie później. Zaplanowanie uroczystego zakończenia procesu pokojowego w stolicy Francji miało przełamać poczatkowa niechęć władz tego kraju do wyboru amerykańskiego Dayton jako miejsca najważniejszych rozmów - zob. R. Holbrooke, Zauršiti rat, Sarajevo 1998, s. 204.

${ }^{2}$ Oficjalna nazwa to Dayton Peace Agreement (DPA), czyli Porozumienie Pokojowe z Dayton. Można również spotkać w literaturze skrót GDPA (G - od General - czyli Ogólne).

${ }^{3}$ Jak uważa Mirko Pejanović, podstawowe cele, które starano się zrealizować podczas obrad w Dayton, to doprowadzenie do: zakończenia wojny w Bośni i Hercegowinie, uzyskania międzynarodowych gwarancji dla istnienia państwa, zbudowania systemu politycznego poprzez opracowanie nowej konstytucji, powrotu uchodźców i wypędzonych do przedwojennych miejsc zamieszkania, ochrony praw człowieka według standardów międzynarodowych, reintegracji społeczeństwa i państwa, ustanowienia demokracji i instytucji demokratycznych - zob. M. Pejanović, Politički razvitak Bosne i Hercegovine u postdejtonskom periodu, Sarajevo 2005, s. 124. 
wała taki stan, że część ekspertów zaczęła zaliczać Bośnię i Hercegowinę do grona państw upadłych (failed state), które przez swoją niestabilność stanowią zagrożenie dla innych ${ }^{4}$.

Wyraźna stała się konieczność zastapienia dotychczasowego modelu, tzw. systemu daytońskiego, nowym, a przynajmniej jego głęboka przebudowa. Tenże proces został scharakteryzowany w 2004 r. przez Paddy'ego Ashdowna, stojacego na czele Biura Wysokiego Przedstawiciela wspólnoty międzynarodowej (OHR), jako

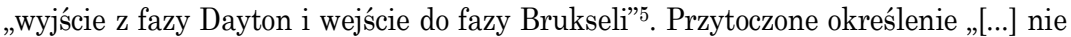
odnosi się oczywiście do uwarunkowań geograficznych, ale do przyjętej przez Bośnię i Hercegowinę reformatorskiej drogi w stronę Unii Europejskiej i NATO”6. Podobne stwierdzenie sformułował przed kilkoma laty Nikola Radovanović: „W dziesięć lat po rozpoczęciu procesu pokojowego mówimy o końcu fazy Dayton i rozpoczęciu fazy Brukseli lub, innymi słowy, o Bośni i Hercegowinie będącej na drodze do integracji z organizacjami euro-atlantyckimi”’. Poniższe opracowanie ma stanowić próbę odpowiedzi na pytanie o szanse i perspektywy takiej zmiany.

Porozumienie pokojowe i jego wplyw na kształt i funkcjonowanie państwa (zarys problemu). Podstawowe cechy „systemu daytońskiego"

Zawarte w Dayton porozumienie jest aktem niezwykle rozbudowanym, a przez to i skomplikowanym. Składa się z jedenastu artykułów oraz takiej samej liczby znacznie obszerniejszych aneksów ${ }^{8}$. Z punktu widzenia funkcjonowania systemu polityczno-ustrojowego i jego ewentualnej transformacji najważniejszy jest Aneks nr IV, który zawiera tekst Konstytucji Bośni i Hercegowiny ${ }^{9}$. Jej forma

\footnotetext{
${ }^{4}$ Szerzej na ten temat zob. R. Báchora, Bośnia i Hercegowina państwem upadtym? Kwestia ekstremizmu muzułmańskiego, [w:] Europejski protektorat? Bośnia i Hercegowina w perspektywie środkowoeuropejskiej, red. M. Gniazdowski, Warszawa 2008, s. 123.

5 S. Turčalo, Međunarodna zajednica i izgradnja neuspješne države, „Status” 2008, br. 13, s. 22

${ }_{6}^{6}$ D. Majstorović, Izgubljeni u prevodu, izgubljeni u tranziciji: Diskurs međunarodne zajednice u konstruisanju tranzicije u BiH, „Status” 2008, br. 13, s. 33.

${ }^{7}$ N. Radovanović, Bosnia and Herzegovina and the „Dayton Process”, „Südosteuropa Mitteilungen" 2005, Heft 4-5, s. 68.

8 Pełny tekst jest dostępny na oficjalnej stronie Wysokiego Przedstawiciela wspólnoty międzynarodowej - http://www.ohr.int/dpa/default.asp?ontent_id=379.

9 Interesujacym przyczynkiem do rozważań o funkcjonowaniu organów władzy w Bośni i Hercegowinie może być informacja, że przechowywany w Sarajewie oryginalny tekst porozumienia zaginął na początku $2008 \mathrm{r}$. Konieczne okazało się sprowadzenie z Paryża uwierzytelnionej kopii wraz ze wszystkimi aneksami i poddanie jej ponownemu tłumaczeniu, tym razem oficjalnemu - wcześniej takowego nie było! Zob. BiH napokon dobiva ustav na svom jeziku: Otkrivamo zašto Dodik plaća prijevod!, 17 V 2010, http://www.dnevnik.ba.
} 
i sposób opracowania stanowią doskonałą egzemplifikację i jednocześnie charakterystykę „systemu daytońskiego" - napisana jest wyłącznie w języku angielskim przez zagranicznych, głównie amerykańskich prawników, a przy jej przyjmowaniu nie zachowano jakichkolwiek procedur, przewidzianych przez wciąż wówczas obowiąująca ustawę zasadniczą Republiki Bośni i Hercegowiny z 1974 r. To dało z kolei asumpt do podważania jej legitymizmu przez część polityków i prawników ${ }^{10}$. Ponadto niezależnie od przyjętych $\mathrm{w}$ konstytucji rozwiązań instytucjonalno-prawnych, największymi kompetencjami dysponuje Wysoki Przedstawiciel.

Analizując zarówno tekst konstytucji, jak i całe porozumienie, można wskazać za Edinem Šarčeviciem kilka najważniejszych cech „systemu daytońskiego”:

a) uregulowanie materii prawno-konstytucyjnej porozumieniem międzynarodowym;

b) etnizację ustrojodawcy poprzez odsunięcie na plan dalszy abstrakcyjnego obywatela jako nosiciela władzy ustrojodawczej;

c) tymczasowość rozwiazań, przekształconą w trwały system prawnokonstytucyjny;

d) usankcjonowanie bezprawia i przekształcenie efektów konfliktu oraz zbrodni wojennych w stosunki publiczno-prawne, czego przejawem jest utworzenie dwóch podmiotów (Republiki Serbskiej i Federacji Bośni i Hercegowiny) de facto w oparciu o przebieg linii frontu w $1995 \mathrm{r}$.;

e) etniczną demokrację, która wymaga osiagnięcia etnicznego porozumienia we wszystkich sprawach państwowych, połączona z permanentnym konfliktem między przedstawicielami narodów konstytutywnych (Bośniakami ${ }^{11}$, Serbami i Chorwatami);

f) etniczny determinizm przy podejmowaniu decyzji w organach władzy;

g) aktywną obecność czynnika zewnętrznego przy kierowaniu państwem;

h) utratę suwerenności wewnętrznej poprzez osłabianie organów władzy państwowej;

i) zawieszenie aktywnej ochrony oficjalnie zaakceptowanych praw człowieka;

j) sprzeczności między deklarowanymi pryncypiami a podstawowymi rozwiązaniami konstytucyjnymi ${ }^{12}$.

${ }^{10}$ C. Steiner, Geneza i legitimnost Ustava Bosne i Hercegovine, „Status” 2006, br. 9, s. 158.

${ }^{11} \mathrm{~W}$ tej pracy będzie używane określenie Bośniacy w stosunku do obywateli Bośni i Hercegowiny wyznających islam. Należy jednak pamiętać, że do 1993 r. ta grupa narodowa nosiła oficjalną nazwę Muzułmanie. $\mathrm{O}$ zawiłościach związanych z nazewnictwem narodów - zob. W. Rybicki, O nazewnictwie państwowym Bośni $i$ Hercegowiny, „Biuletyn PISM" 2001, nr 8.

12 E. Sarčević, Deytonski ustav: karakteristike i karakteristični problemi, Sarajevo 2009, s. 85 . 
Jak łatwo można zauważyć, przedstawione powyżej cechy systemu maja zdecydowanie negatywny wydźwięk, co wskazuje na niepowodzenie przyjętego w Dayton modelu. Taki pogląd podziela m.in. Kasim Trnka, były sędzia Sądu Konstytucyjnego Bośni i Hercegowiny, który wymienia kilka najważniejszych jego zdaniem - wad porozumienia:

a) w tekście nie znalazło się żadne odniesienie do przyczyn i charakteru wojny;

b) wynik działań zbrojnych stanowił punkt wyjścia nowego porządku i podziału kraju;

c) Bośnię i Hercegowinę podzielono na jednostki (etniteti), które nigdy wcześniej nie funkcjonowały;

d) nie zostały opracowane efektywne mechanizmy eliminacji skutków „czystek etnicznych” ani nie sprecyzowano roli wspólnoty międzynarodowej w stosunku do organów władzy, gdyby te nie wypełniały zadań nałożonych wobec uchodźców;

e) porozumienie usankcjonowało powstanie kompletnie nieefektywnej, niefunkcjonalnej i przerośniętej struktury władzy oraz asymetrycznych jednostek (zdecentralizowanej Federacji i scentralizowanej Republiki), jak też nie rozwiązało w pełni sprawy miasta Brčko, podzielonego Mostaru i stołecznego statusu Sarajewa;

f) narzucony został system wyborczy, który okazał się sprzeczny z podstawowymi standardami demokracji, pozbawiając podstawowych praw blisko trzecia część mieszkańców;

g) najważniejszym czynnikiem w strukturze i funkcjonowaniu organów władzy publicznej stała się przynależność etniczna, stawiana wyżej niż prawa obywatelskie;

h) kreatorzy „systemu daytońskiego” od samego początku zdawali sobie sprawę, że nie jest on $\mathrm{w}$ stanie samodzielnie funkcjonować, dlatego z góry przewidziano znaczny udział przedstawicieli wspólnoty międzynarodowej w jego podtrzymywaniu ${ }^{13}$.

Niemniej w literaturze można znaleźć przykłady wskazujace na pozytywne efekty zawarcia porozumienia. Przede wszystkim, wbrew czarnym scenariuszom, nie doszło do rozpadu państwa na dwa niezależne byty, czyli Republikę i Federację, co upodobniłoby Bośnię i Hercegowinę do podzielonej Korei. Amerykańska sekretarz stanu Hillary Clinton w 15. rocznicę podpisania porozumienia w Dayton stwierdziła, że stanowi ono „kamień węgielny pokoju i stabilności w Bośni i Hercegowinie" ${ }^{14}$. Równie pozytywna rolę porozumienie odegrało dla powrotu znacznej części uchodźców, a przynajmniej tych, którzy

${ }_{13} \mathrm{~K}$. Trnka, Ustaune promjene ispod realnih potreba $i$ demokratskog legitimiteta, Status" 2006, br. 9, s. 162.

${ }_{14}$ A. Zornija, Obilježena 15. obljetnica Daytona: Različiti pogledi kako dalje, 21 XI 2010, http://www.vjesnik.hr. 
zdecydowali się wrócić do miejsca zamieszkania sprzed wojny ${ }^{15}$. Jednakże nie jest to wybitna skala osiagnięć i trudno uznać, iż równoważą one negatywne skutki „systemu daytońskiego".

Funkcjonujący w Bośni i Hercegowinie model oparty jest z jednej strony na elementach konsocjonalizmu, a z drugiej - etnokracji - czyli łączy w sobie cechy systemu demokratycznego oraz quasi- czy wręcz niedemokratycznego ${ }^{16}$. Pierwsza ze wspomnianych koncepcji, czyli konsocjonalizm, którą Arend Lijphart stworzył w opozycji do modelu westminsterskiego, zakłada następujące rozwiązania:

a) istnienie wielkiej koalicji, oznaczającej praktykę tworzenia porozumień parlamentarnych i rządowych z udziałem tak wielkiej liczby partii, jak tylko to jest możliwe;

b) wzajemne weto, którym dysponują wszystkie mniejszości;

c) proporcjonalny system wyborczy, ułatwiający dostęp do parlamentu nawet małym ugrupowaniom politycznym;

d) zapewnienie autonomii, pozwalającej na załatwienie maksymalnej liczby spraw dotyczących poszczególnych mniejszości, w ich obrębie i siłami reprezentujących je instytucji ${ }^{17}$.

Analizując treść Konstytucji Bośni i Hercegowiny pod kątem zgodności z przedstawionymi powyżej założeniami, nie sposób nie zgodzić się z opinią, że porozumienie z Dayton można uznać niemalże za „klasyczny przykład rozstrzygnięcia konsocjonalnego, gdyż wymaga od elit zastosowania podziału władzy (power sharing) oraz zakłada proporcjonalny układ w organach władzy, a także gwarantuje prawo weta i autonomię poszczególnych wspólnot"18.

Tym, co odróżnia model funkcjonujący w Bośni i Hercegowinie od wzorca zaproponowanego przez A. Lijpharta, jest zastosowanie elementów etnokracji. Pod pojęciem tym można rozumieć sytuację, w której „[...] etniczna przynależność decyduje o politycznym statusie. Jej rzeczywisty sens nie odnosi się do rządów konkretnego narodu w wielonarodowej wspólnocie, ale do samej możliwości, że naród jako ethnos generalnie może rządzić. [...] Wszystko to konkretyzuje się porządkiem konstytucyjnym. Etnokracja w każdym przypadku oznacza pozbawienie abstrakcyjnego obywatela fundamentalnej roli w państwie i przekazanie jej w decydującym stopniu narodowi i jego potrzebom"19. Z taką definicją zgadza się

${ }^{15}$ M. Søberg, Empowering Local Elites in Bosnia and Herzegovina. The Dayton Decade, „Problem of Post-Communism” 2006, no. 3, s. 44

16 Szerzej na temat możliwych rozwiązań systemowych stosowanych w społeczeństwach o skomplikowanej strukturze etnicznej zob.: S. Smooha, The Model of Ethnic Democracy, ,ECMI Working Paper” 2001, no. 13.

${ }^{17}$ A. Antoszewski, Modele demokracji przedstawicielskiej, [w:] Demokracje zachodnioeuropejskie. Analiza porównawcza, red. A. Antoszewski, R. Herbut, Wrocław 2008, s. 32.

${ }_{18}$ R. Belloni, Bosnia: Dayton is Dead! Long Live Dayton!, "Nationalism and Ethnic Politics" 2009, no. 15, s. 359 .

${ }^{19}$ E. Šarčević, Deytonski Ustav: karakteristike i problemi, ,Status” 2008, br. 13, s. 168. 
Nurko Pobrić, pisząc - w odniesieniu do porozumienia z Dayton - że: „Podstawową słabością konstytucji [...] jest fakt, że organizacja władzy państwowej opiera się na preferowaniu osób lub kolektywów reprezentujacych grupy etniczne [...]. Wola polityczna [...] jest wyrażana jako wola etniczna, a decydowanie polityczne jako decydowanie etniczne"20.

Z perspektywy piętnastu lat trzeba stwierdzić, że zmiany wymagają rozwiązania opartego zarówno na modelu konsocjonalnym, jak i - tym bardziej etnokratycznym. Nie sprawdziła się w Bośni i Hercegowinie ambitna propozycja A. Lijpharta, gdyż przede wszystkim zabrakło zaufania między politycznymi przedstawicielami Bośniaków, Serbów i Chorwatów. Ich cele były i są zdecydowanie rozbieżne, a dodatkowo wyraźna jest niezdolność stron do zawierania kompromisów, które sa niezbędne dla funkcjonowania konsocjonalizmu ${ }^{21}$. Natomiast rozwiązania zaczerpnięte $\mathrm{z}$ etnokracji, które wykluczaja część obywateli z pełnego udziału w życiu politycznym tylko dlatego, że nie należa oni do jednego $\mathrm{z}$ trzech narodów konstytutywnych, nie przystaja pod żadnym względem do europejskich aspiracji Sarajewa ze względu na ich ewidentna sprzeczność nie tylko z prawem unijnym, ale i niektórymi fundamentalnymi konwencjami międzynarodowymi. Ten „konsocjonalny etnonacjonalistyczny Daytonland", jak określił Bośnię i Hercegowinę Asim Mujkić, musi zostać poddany głębokiej reformie, aby rzeczywiście można było mówić o transformacji „od Dayton do Brukseli”22.

\section{Udane i nieudane próby zmiany systemu}

Przyjęte w Dayton rozwiązania bardzo szybko okazały się niefunkcjonalne. Stało się tak w dużej mierze $\mathrm{w}$ następstwie zbyt optymistycznego podejścia przedstawicieli wspólnoty międzynarodowej do wizji powojennej współpracy

${ }^{20}$ N. Pobrić, Elements of Ethnic Federalism in the Bosnia and Herzegovina Constitutional System, „Dialogue International Edition” 1998, no. 7-8, s. 103.

${ }_{21}$ Od dłuższego czasu toczy sie dyskusja między politologami i socjologami na temat przyszłości demokracji konsocjonalnej w Bośni i Hercegowinie. Stosunek do niej zasadniczo zależy od przynależności narodowej autora: Bośniacy w większości są przeciwni, Chorwaci zdecydowanie za, natomiast Serbowie - raczej za. Szerzej na ten temat zob. E. Delibašić, Između etnosa $i$ demosa, Zenica 2008, s. 129-146.

22 A. Mujkić, Mi, građani etnopolisa, Sarajevo 2007, s. 28. W literaturze przedmiotu można znaleźć innych wiele ciekawych określeń „systemu daytońskiego”, np. „równoległe funkcjonowanie wyborów rywalizacyjnych, systemu parlamentarnego i wielopartyjnego, definiowanych etnicznie instytucji państwowych i autorytarnego arbitra międzynarodowego pół-protektoratu" - zob. B. Weber, Političke elite i politička kultura u BiH i izazovi evropskih integracja, [w:] Bosna i Hercegovina i proturječnosti procesa EU integracija, Sarajevo 2008, s. 24 . 
między trzema narodami konstytutywnymi. Brak postępu w normalizacji sytuacji w Bośni i Hercegowinie zmusił Radę do spraw Wdrażania Pokoju (PIC) ${ }^{23}$ do podjęcia na spotkaniu w Bonn w grudniu 1997 r. decyzji o znacznym rozszerzeniu kompetencji OHR (tzw. uprawnienia bońskie - Bonn powers, Bonske ovlasti). W ich ramach Wysoki Przedstawiciel uzyskał m.in. możliwość odwoływania wszystkich osób sprawujących funkcje publiczne, jeżeli stanowią zagrożenie dla przebiegu procesu pokojowego, jak też prawo do narzucania ustaw (a nawet zmian w konstytucjach jednostek), jeżeli właściwe organy prawodawcze nie będa wywiazywać się ze swoich zadań ${ }^{24}$. O skali aktywności prawodawczej OHR niech świadczy fakt, iż w latach 1997-2007 narzucił on aż 112 ustaw z zakresu działalności Skupštiny Bośni i Hercegowiny, wobec 279 uchwalonych przez parlament ${ }^{25}$. Ta pozakonstytucyjna instytucja i zakres jej kompetencji powoduje, że tradycyjny nosiciel władzy ustawodawczej ma znacznie ograniczone możliwości działania. Wielu prawników i politologów wprost twierdzi, że sama możliwość skorzystania przez OHR z „uprawnień bońskich” powoduje, że Bośnia i Hercegowina nie jest państwem niepodległym ${ }^{26}$.

Wprowadzenie „uprawnień bońskich” było pierwszym poważnym przejawem modyfikacji „systemu daytońskiego”. Kolejnym, dokonanym zreszta z ich wykorzystaniem, było usunięcie, dyskryminacyjnych wobec członków narodów konstytutywnych, postanowień z konstytucji jednostek - Republiki Serbskiej i Federacji Bośni i Hercegowiny. W tej pierwszej, pełne prawa przyznane były tylko Serbom, natomiast w drugiej - Bośniakom i Chorwatom. Proces zmian został zapoczątkowany przez działająca jeszcze od czasów wojny na terytorium Federacji Serbską Radę Obywatelską (Srpsko građansko vijeće, SGV), która w 1997 r. zażądała zmian w konstytucjach jednostek, a przede wszystkim Federacji, i usunięcia zaskarżonych postanowień. Wprawdzie parlament jednostki nie zajął się tym zagadnieniem, jednak problem stał się głośny. W następnym roku Alija Izetbegović, będący wówczas przewodniczącym Prezydium Bośni i Hercegowiny, przedłożył sprawę Sądowi Konstytucyjnemu twierdząc, że wskazane rozwiązania sa sprzeczne z Konstytucją Bośni i Hercegowiny. Organ ten przyznał rację skarżącemu i w czterech wyrokach, wydanych

${ }^{23}$ PIC składa się z pięćdziesięciu pięciu członków - zarówno państw, jak i organizacji międzynarodowych.

${ }^{24}$ T.K. Vogel, Bosnia and Herzegovina. The Challenge of Legitymacy, Bern 2006, s. 6.

${ }^{25}$ K. Trnka, Evaluacija procesa odlučivanja u Parlamentarnoj skupštini BiH - 19962007. godine, [w:] Proces odlučivanja u Parlamentarnoj skupštini Bosne i Hercegovine. Stanje - komparativne rješenja - prijedlozi, [ur. I. Marić], Sarajevo 2009, s. 96. Warto dodać, że decyzjami OHR powołano do życia tak ważne instytucje, jak Sąd Bośni i Hercegowiny, Prokuratora Generalnego czy ombudsmana.

${ }^{26}$ D. Pehar, O iracionalnostima u političkom tumačenju Daytonske strukture za Bosnu $i$ Hercegovinu - lekcije za domaće i inozemne političare, „Status” 2004, br. 5, s. 86. 
w styczniu, lutym, lipcu i sierpniu 2000 r., uznał istotne części ustaw zasadniczych obu jednostek za sprzeczne z państwową ustawą zasadniczą ${ }^{27}$.

Sama decyzja Sądu Konstytucyjnego, przyjęta zresztą tylko głosami sędziów bośniackich i zagranicznych, przy sprzeciwie członków wybranych przez Serbów i Chorwatów ${ }^{28}$, nie oznaczała jeszcze zakończenia procesu. Posłowie w obu jednostkach niezwykle opornie pracowali nad nowymi rozwiązaniami. Przełamanie politycznego pata nastapiło dopiero 19 kwietnia 2002 r., gdy Wysoki Przedstawiciel, którym był wówczas Wolfgang Petrisch, korzystając z „uprawnień bońskich", wprowadził odpowiednie zmiany do konstytucji Republiki Serbskiej oraz Federacji Bośni i Hercegowiny ${ }^{29}$. W ich wyniku wszystkie trzy główne narody otrzymały status konstytutywnych na całym obszarze państwa. W dalszej kolejności, na mocy tzw. porozumienia sarajewskiego (Sarajevski dogovor), uzgodniono zastosowanie odpowiedniego klucza narodowego przy podziale stanowisk, przede wszystkim w organach władz ustawodawczych i wykonaw$\operatorname{czych}^{30}$.

Kolejne kroki w procesie rewizji Dayton obejmowały przeniesienie na poziom centralny kompetencji w zakresie bezpieczeństwa, spraw wewnętrznych oraz polityki fiskalnej, a także utworzenie Państwowej Służby Granicznej (Držauna granična služba) i administracji podatkowej. Za bardzo ważny czynnik uznać można utworzenie Ministerstwa Obrony, co umożliwiło ujednolicenie prowadzonej polityki obronnej ${ }^{31}$. Również powołanie do życia Sądu Bośni i Hercegowiny, którego brak w systemie sądownictwa powszechnego był bardzo wyraźny, przemawia za stopniowym odchodzeniem od ścisłego trzymania się postanowień z Dayton ${ }^{32}$.

Na podjęcie najpoważniejszej próby reformy ustroju narzuconego w Dayton w największym stopniu wpłynęła, paradoksalnie, amerykańska administracja. W dziesięć lat po podpisaniu porozumienia, jesienią 2005 r., pod kierownictwem ambasadora USA w Sarajewie oraz z poparciem samej sekretarz stanu Condo-

${ }^{27}$ F. Bieber, Bosna i Hercegovina poslije rata. Politički sistem u podjeljenom društvu, Sarajevo 2008, s. 139-140.

${ }^{28}$ Sąd Konstytucyjny liczy dziewięciu członków, z czego czterech nie może być obywatelami Bośni i Hercegowiny ani żadnego z sasiednich państw (art. VI Konstytucji Bośni i Hercegowiny; tekst dostępny na stronie http://www.ohr.int/dpa/default.asp?content_id=372). Warto podkreślić, że Sąd Konstytucyjny jest jedynym organem władzy na szczeblu centralnym, gdzie nie istnieje $z$ góry określona zasada podziału miejsc ze względu na przynależność etniczną ani nie funkcjonują żadne procedury blokowania decyzji w celu ochrony żywotnych interesów narodów konstytutywnych.

${ }^{29}$ F. Bieber, $d z$. cyt., s. 148 .

${ }^{30}$ Zob. W. Stanisławski, M. Szpala, Bośniacki chaos. Źródła kryzysu politycznego we wspótczesnej Bośni i Hercegowinie, „Prace OSW”, październik 2009, nr 31, s. 84.

${ }^{31}$ Z. Jukić, Planovi ustavnog i teritorialnog preustroja BiH 1992.-1995., „Status” 2004, br. 5, s. 69.

32 T.K. Vogel, dz. cyt., s. 27. 
leezzy Rice, rozpoczęły się rozmowy przedstawicieli najważniejszych partii politycznych z Bośni i Hercegowiny. Ostatecznie wypracowany został pakiet zmian konstytucyjnych, który miał ułatwić podejmowanie decyzji w parlamencie i doprowadzić do poprawy funkcjonowania państwa. Podpisali się pod nim liderzy Partii Akcji Demokratycznej (SDA), Chorwackiej Wspólnoty Demokratycznej Bośni i Hercegowiny (HDZ BiH), Partii Postępu Demokratycznego (PDP), Związku Niezależnych Socjaldemokratów (SNSD) i Serbskiej Partii Demokratycznej (SDS). Zaproponowane reformy (tzw. pakiet kwietniowy - aprilski paket) zostały odrzucone przez niższą izbę parlamentu w Sarajewie, gdyż nie uzyskano wymaganego poparcia $2 / 3$ głosów. W ten sposób zakończyła się najbardziej zaawansowana próba głębokiej przebudowy ustrojowej części „systemu daytońskiego" 33 .

Następne podejście do problemu reformy prawno-instytucjonalnej miało miejsce pod koniec 2008 r. W dniu 8 grudnia, w położonej w północnej części kraju miejscowości Prud, spotkali się liderzy trzech partii, reprezentujących wszystkie narody konstytutywne. Przedstawicielem strony bośniackiej był Sulejman Tihić, lider SDA, serbskiej - Milorad Dodik, przywódca SNSD oraz ówczesny premier Republiki Serbskiej, natomiast stronę chorwacką reprezentował Dragan Čović, przewodniczący HDZ BiH. Po spotkaniu jego uczestnicy ogłosili, że doszli do porozumienia w kluczowych dla przyszłości Bośni i Hercegowiny sprawach (podziału własności, Dystryktu Brčko, spisu powszechnego, budżetu centralnego oraz reform konstytucyjnych). Początkowy entuzjazm szybko ustapił miejsca rozczarowaniu, gdy okazało się, że były to jedynie ogólne uzgodnienia. $\mathrm{Na}$ kolejnych trzech spotkaniach (22 grudnia, 26 stycznia oraz 21 lutego) nie udało się dopracować konkretnych rozwiązań, szczególnie w kluczowej kwestii zmiany konstytucji, co spowodowało, iż „prudski proces”, mimo zrealizowania niektórych elementów (np. przyjęcia budżetu), okazał się porażką ${ }^{34}$.

Po niepowodzeniu kolejnej próby reform, podjętej przez lokalnych liderów, inicjatywa wróciła do polityków Stanów Zjednoczonych i Unii Europejskiej. W październiku 2009 r. odbył się w bazie wojskowej sił EUFOR w Butmir szereg spotkań, w których, oprócz przedstawicieli najważniejszych parlamentarnych partii politycznych, bezpośredni udział wzięli m.in. Carl Bildt (szwedzki minister spraw zagranicznych, reprezentujący UE) oraz James Steinberg (zastępca sekretarza stanu) ${ }^{35}$. Co warte podkreślenia, prawie zupełnie z rozmów wykluczony został Wysoki Przedstawiciel wspólnoty międzynarodowej. Pełniącego tę

${ }^{33}$ F. Borić, Posljedni mohikanac OHR-a: Spašavanje diplomate Lajčaka - slika i prilika odnosa međunarodne zajednice prema BiH, ,Status” 2008, br. 13, s. 53.

${ }^{34}$ Bosnia's Incomplete Transition: Between Dayton and Europe, „Europe Report”, no. 198, International Crisis Group, 9 III 2009, s. 4-5.

${ }^{35}$ Nastavlja se Butmirski proces u BiH, 22 X 2009, http://www.setimes.com. 
funkcję Valentina Inzko zaproszono tylko jako przedstawiciela misji UE, zatem nie odgrywał głównej roli w tym spotkaniu ${ }^{36}$.

Pod obrady przedłożona została propozycja głębokich zmian w strukturach władzy centralnej, m.in. powiększenie liczby deputowanych w izbie niższej parlamentu (Przedstawicielskiej), przy jednoczesnym pozbawieniu izby wyższej (Narodów) kompetencji ustawodawczych, powołanie silnego rządu w miejsce słabej Rady Ministrów oraz utworzenie instytucji prezydenta, mającego dwóch zastępców. Jednak, co istotne, nie miały zostać w sposób poważny naruszone procedury, które służa do ochrony podstawowych interesów narodów konstytutywnych ${ }^{37}$. Mimo presji ze strony przedstawicieli wspólnoty międzynarodowej, połączonej z obietnica zniesienia OHR w razie zawarcia porozumienia, większość miejscowych polityków bioracych udział w obradach odrzuciła „pakiet butmirski”. Powody takiej decyzji były jednak odmienne - dla liderów serbskich i chorwackich propozycje i tak szły za daleko, a dla bośniackich bądź stanowiły tylko krok we właściwą stronę, bądź można je było zaakceptować jedynie warunkowo ${ }^{38}$.

\section{Z Dayton do Brukseli? Perspektywa reform społeczno-politycznych w Bośni i Hercegowinie}

Spośród całego szeregu istotnych problemów, które mają wpływ na obecna sytuację w Bośni i Hercegowinie, a także rzutują na szansę transformacji społeczno-politycznej i odejście od „systemu daytońskiego” na rzecz „fazy Brukseli”, kilka zasługuje na szczególną uwagę. Omówimy je poniżej.

Przekształcenie OHR. Jedną z najpoważniejszych kwestii, która wymaga podjęcia zdecydowanych działań politycznych, jest dalsze funkcjonowanie Wysokiego Przedstawiciela wspólnoty międzynarodowej, który od 2002 r. pełni równocześnie funkcję Specjalnego Przedstawiciela Unii Europejskiej (EUSR). Obdarzony na mocy „uprawnień bońskich” praktycznie nieograniczonymi kompetencjami władczymi, z jednej strony - nadzoruje wprawdzie przebieg procesu stabilizacji w tym głęboko podzielonym państwie, jednakże z drugiej w sposób ewidentny ogranicza pole działania demokratycznie przecież wybranych przedstawicieli. Dominująca rolę OHR w systemie politycznym Bośni i Hercegowiny doskonale scharakteryzował były (do listopada 2010 r.) premier tego kraju, Serb Nikola Špirić: „Jeśli wspólnota międzynarodowa ciagle będzie wspierała

${ }^{36}$ Bosnia’s Dual Crisis, „Europe Briefing”, no. 57, International Crisis Group, 12 XI 2009, s. 4

${ }^{37}$ R. Šegrt, Predložene promjene Ustava BiH, 19 X 2009, http://www.nezavisne.com.

${ }_{38}$ Tihić uslouno prihuatio, SBiH, HDZ BiH i SNSD odbili butmirski paket!, $20 \mathrm{X}$ 2009, http://www.dnevniavaz.ba. 
działalność Wysokiego Przedstawiciela, a nie instytucje państwowe, to nie będzie miało znaczenia, czy na fotelu szefa rządu będę ja, czy Bart Simpson" ${ }^{39}$. Rację zatem mają ci autorzy, którzy porównuja model funkcjonowania OHR do panowania austro-węgierskiego, czyli lat 1878-1914, kiedy główną rolę w Bośni i Hercegowinie odgrywali zarządcy przysyłani przez cesarza Franciszka Józefa ${ }^{40}$. Funkcjonowanie tej instytucji może być tym bardziej frustrujace dla miejscowych działaczy politycznych, iz praktyka piętnastu lat istnienia OHR wykazała, iż nieraz byli to „trzeciorzędni politycy z drugorzędnych krajów” 41 .

Bez watpienia likwidacja instytucji Wysokiego Przedstawiciela i pełne zastapienie jej przez EUSR, posiadającego tylko kompetencje o charakterze pomocniczo-doradczym, jest swoistym „papierkiem lakmusowym” przejścia „od Dayton do Brukseli”. Po raz pierwszy taka propozycja pojawiła się w $2006 \mathrm{r}$. Założono wówczas, że proces ten zakończy się do końca czerwca 2007 r., jednak znaczące pogorszenie się sytuacji politycznej w kraju, po odrzuceniu „pakietu kwietniowego" i jesiennych wyborach, przekreśliło te plany ${ }^{42}$.

W lutym 2008 r. Rada ds. Wdrażania Pokoju podjęła decyzję, że OHR zostanie przekształcony w EUSR wtedy, gdy Bośnia i Hercegowina zrealizuje pięć celów oraz wypełni dwa warunki. Do celów zaliczono: przeprowadzenie podziału majątku państwowego między centralny i pozostałe poziomy władzy, uregulowanie problemu własności majątku wojskowego, pełną realizację arbitrażu dotyczącego spornego Dystryktu Brčko, stabilność i funkcjonalność instytucji podatkowych oraz umocnienie rządów prawa (m.in. ściganie zbrodniarzy wojennych). Do warunków natomiast zaliczono: podpisanie Porozumienia o Stabilizacji i Stowarzyszaniu (SAA) i pozytywną ocenę sytuacji ze strony Komitetu Sterujacego PIC ${ }^{43}$. Tym samym pojawiła się realna perspektywa zmian, chociaż nie jest ona do końca ściśle zdefiniowana, bo np. trudno jednoznacznie wskazać przesłanki umożliwiające „pozytywną ocenę sytuacji”. Część powyższych celów i warunków już została zrealizowana, np. w marcu 2009 r. dokonano pierwszej nowelizacji Konstytucji Bośni i Hercegowiny, wpisując do niej postanowienia dotyczące Dystryktu Brčko, a w czerwcu 2008 r. podpisano SAA. Niemniej trudno pokusić się choćby o próbę wskazania realnego terminu przekształcenia OHR w EUSR.

Utrzymanie bądź zmiana struktury terytorialnej państwa. Przyjęty w $1995 \mathrm{r}$. podział administracyjny państwa opierał się na rezultatach wojny, gdyż de facto stanowił odwzorowanie $-\mathrm{z}$ niewielkimi zmianami - linii rozdziału

${ }^{39}$ Cyt. za: S. Rammel, Međunarodne sile, gradnja države i nacije u Bosni i Hercegovini: Od neokolonijalne Medunarodne zajednice do post-hegemone Europe?, „Status” 2008, br. 13, s. 12 .

${ }^{40}$ S. Bose, Formulating an International Strategy for Bosnia and Herzegovina, ,Südosteuropa Mitteilungen” 2005, Heft 4-5, s. 102.

${ }^{41}$ F. Borić, $d z$. cyt., s. 54.

${ }^{42}$ Bosnia's Incomplete Transition..., s. 1.

${ }^{43}$ Tamże. 
wrogich wojsk. Potwierdzenie w Dayton istnienia powołanej w 1992 r. Republiki Serbskiej oraz utworzonej dwa lata później Federacji Bośni i Hercegowiny jest bodajże największym problemem przy ewentualnej reformie administracyjnej. Dla Serbów istnienie „ich” jednostki jest gwarancją zachowania praw i obroną przed ewentualnym zdominowaniem na poziomie ogólnokrajowym przez liczniejszych Bośniaków. Republika „[...] ma swoje autochtoniczne instytucje, mieszkańców, którzy je akceptuja, pragną i chca, i która ma [...] własne terytorium, większe od niejednego kraju, nie tylko Czarnogóry, i która może ustanowić specjalne, równoległe stosunki z innymi, przede wszystkim z państwem-matką Serbią" ${ }^{44}$. Chęć utrzymania dotychczasowych rozwiązań stała się szczególnie widoczna podczas rozmów w Prudzie, gdzie wprawdzie początkowo M. Dodik zgodził się na zmianę ustroju administracyjnego Bośni i Hercegowiny, ale później wyjaśnił, że nie może to dotyczyć obszaru Republiki Serbskiej.

Niezgoda na likwidację Republiki jest i zapewne długo będzie najpoważniejszą przeszkodą w ewentualnej rewizji podziału terytorialnego Bośni i Hercegowiny. Co więcej, obrona jedności i odrębności tej jednostki przełożyła się na traktowanie całego porozumienia z Dayton jako wyjątkowo korzystnego dla serbskiego narodu, przez co bardzo niechętnie ich liderzy polityczni odnoszą się do zmian „systemu daytońskiego”. Szczególnie dotyczy to przenoszenia kolejnych kompetencji z jednostek na poziom centralny ${ }^{45}$. Czołowi serbscy politycy w Bośni i Hercegowinie jasno deklaruja, że dla nich porozumienie z 1995 r. jest idealnym rozwiązaniem i nie widzą konieczności większych zmian ${ }^{46}$. Bardzo symptomatyczne jest w tym przypadku hasło, które przyświecało M. Dodikowi w kampanii wyborczej prowadzonej jesienia 2010 r.: „Serbska na zawsze, a Bośnia dopóki trzeba" (Srpska zauvek, a BiH dok mora) ${ }^{47}$.

Nieco inaczej patrzą na możliwość zmiany struktury terytorialnej przedstawiciele dwóch pozostałych narodów konstytutywnych - Bośniaków i Chorwatów.

${ }^{44}$ S. Nagradić, Dvadeset tri teze o istorijskom utemeljenju Republike Srpske, „Nova srpska politička misao. Časopis za političku teoriju i društvena istraživanja”, 1 VII 2009 , http://www.nspm.rs.

${ }_{45}$ Przejawem tej niechęci była deklaracja Skupsztiny Ludowej Republiki Serbskiej przyjeta 29 maja 2010 r., w której skrytykowano osłabianie kompetencji jednostek na rzecz władz centralnych i anulowano ich skutki prawne. Akt ten został nastẹpnie w całości uchylony decyzją Wysokiego Przedstawiciela, V. Inzko, co doprowadziło do kolejnego spięcia na linii OHR-Republika Serbska - zob. D. Spremo, U svetu kvazidemokracije, „Nova srpska politička misao. Časopis za političku teoriju i društvena istraživanja”, 24 VI 2009, http://www.nspm.rs.

${ }^{46} \mathrm{~W}$ takim duchu wypowiadali sie m.in. serbski członek Prezydium Nebojša Radmanović i premier Republiki Serbskiej M. Dodik - zob.: Nema kompromisa kada je u pitanju Dejton, 21 X 2010, http://www.nspm.rs z dnia.

${ }^{47}$ S. Durmanović, Izbori u BiH - trijumf Dodika, brodolom Silajdžicia, „Nova srpska politička misao. Časopis za političku teoriju i društvena istraživanja”, 5 X 2010, http://www.nspm.rs. 
Co zrozumiałe, nie wykluczają - szczególnie ci pierwsi - całkowitej reformy administracyjnej, obejmującej likwidację Republiki Serbskiej i Federacji, i powołanie w ich miejsce kilku regionów. Natomiast wśród Chorwatów dominuje chęć utworzenia własnej jednostki, w której stanowiliby naród dominujący, podobnie jak miało to miejsce $\mathrm{w}$ powołanej w czasie wojny Herceg-Bośni. Przejawem tej tendencji był „bunt” w 2001 r. członków najważniejszego ugrupowania politycznego Chorwatów w Bośni i Hercegowinie, czyli HDZ BiH, polegający na bojkocie instytucji państwowych i powołaniu do życia własnej autonomii. Pragnienie utworzenia samodzielnej jednostki można jednak po części zrozumieć. Chorwaci stanowią najmniejszą grupę spośród trzech narodów konstytutywnych, znacznie mniej liczną niż Bośniacy, a rozwiązania przyjęte w prawie konstytucyjnym Federacji nie zawieraja takich konsocjonalnych zabezpieczeń, jak ma to miejsce w przypadku władz centralnych. Skutek jest taki, że dominujący w tej jednostce przy podejmowaniu decyzji system większościowy premiuje Bośniaków kosztem Chorwatów ${ }^{48}$. Najjaskrawszym tego przykładem jest dwukrotne już wybranie (w 2006 i 2010 r.) do Prezydium Bośni i Hercegowiny Chorwata Željko Komšicia z Socjaldemokratycznej Partii BiH (SDP BiH), który jest oskarżany przez kierownictwo $\mathrm{HDZ}$ o to, iż za jego elekcja stoja Bośniacy, a nie Chorwaci, i że nie reprezentuje on narodowych interesów swojego narodu 49

Niezależnie od różnicy zdań, reforma Federacji jest absolutnie konieczna. Złożona z dziesięciu kantonów (podzielonych z kolei na gminy), obdarzonych własnymi parlamentami i rządami, jest „administracyjnym koszmarem [...], w którym koszty utrzymania administracji są dwukrotnie wyższe niż w Republice Serbskiej ${ }^{50}$. Do tego często brak jest woli współpracy na poziomie władz Federacji, gdyż najważniejsze kompetencje przekazane są na poziom kantonów. Warto dodać, że kantony są podzielone pod względem etnicznym - pięć jest bośniackich, trzy chorwackie i tylko pozostałe dwa mają charakter mieszany ${ }^{51}$.

Do pełni obrazu niesamowicie skomplikowanej struktury terytorialnej należy dodać Dystrykt Brčko. Jako obszar będący obiektem szczególnego sporu,

48 Więcej na ten temat zob. BH Alijansa za (omanje) promjene, „Izvještaj ICG-a za Balkan”, br. 132, International Crisis Group, 2 VIII 2002.

${ }^{49}$ Ordynacja wyborcza dopuszcza taką możliwość, gdyż w Federacji wybiera się bądź przedstawiciela Chorwatów, badź Bośniaków, ale nie trzeba głosować według przynależności etnicznej. Oznacza to, że np. Bośniak może zagłosować na chorwackiego kandydata. Co się tyczy samego Ž. Komšicia, to w czasie wojny walczył w szeregach zdominowanej przez Bośniaków Armii Republiki BiH, a nie wraz z rodakami w oddziałach Chorwackiej Rady Obrony (HVO).

50 Dokładne informacje na temat (nie)funkcjonowania Federacji można znaleźć w: Federation of Bosnia and Herzegovina - A Parallel Crisis, „Europe Report”, no. 209, International Crisis Group, 28 IX 2010.

${ }^{51}$ F. Bieber, dz. cyt., s. 76 . 
utworzony został na mocy decyzji wspólnoty międzynarodowej w 1999 r. (oficjalnie rozpoczął funkcjonowanie w marcu 2000 r.) i działa na mocy osobnego statutu, który gwarantuje mu posiadanie własnych organów władzy ustawodawczej, wykonawczej i sądowniczej. Po nowelizacji Konstytucji Bośni i Hercegowiny w marcu 2009 r. jego istnienie zostało zagwarantowane na poziomie ustawy zasadniczej, co oznacza, iż de facto Bośnia i Hercegowina składa się obecnie z trzech podmiotów o bardzo szerokiej samodzielności.

„Przypadek Sejdić/Finci” i konieczność zmiany systemu wyborczego. Od lat wskazuje się na sprzeczność postanowień Konstytucji Bośni i Hercegowiny $\mathrm{z}$ konwencjami przyjętymi w państwach demokratycznych. Przede wszystkim dotyczy to kwestii kolektywnych praw grup etnicznych, które stawiane sa wyżej niż prawa i wolności jednostki, a także pozbawienia pewnej grupy obywateli praw wyborczych tylko ze względu na przynależność narodową ${ }^{52}$. $\mathrm{Na}$ ten problem wskazała m.in. Komisja Wenecka w jednym ze swoich raportów ${ }^{53}$. Do usunięcia z prawa wyborczego dyskryminujących postanowień (w ciagu roku) władze Bośni i Hercegowiny zobowiązały się w 2002 r., gdy kraj ten stał się członkiem Rady Europy. Niestety, za deklaracjami nie poszły żadne realne działania.

Obowiązujące uregulowania wyborcze pozbawiają część obywateli możliwości kandydowania do niektórych organów władzy. Zgodnie z art. V konstytucji, członkami trzyosobowego Prezydium Bośni i Hercegowiny mogą być: Serb (wybrany z Republiki Serbskiej) oraz Bośniak i Chorwat (wyłonieni na obszarze Federacji). Oznacza to, iż tylko ze względu na przynależność etniczną biernego prawa wyborczego pozbawieni są przedstawiciele innych narodowości na terenie całego kraju oraz Serbowie w Federacji i Bośniacy wraz z Chorwatami, jeżeli mieszkaja w Republice. Równie dyskryminujacy jest art. IV, który zastrzega, że w wyższej izbie parlamentu moga zasiadać tylko przedstawiciele narodów konstytutywnych.

Powyższe regulacje zostały zaskarżone w 2006 r. do Europejskiego Trybunału Praw Człowieka w Strasburgu przez Dervo Sejdicia (przedstawiciela mniejszości romskiej) oraz Jakoba Finci (z mniejszości żydowskiej, wówczas ambasadora Bośni i Hercegowiny w Szwajcarii). Skarżący wskazali na sprzeczność tych postanowień z Europejską Konwencją Ochrony Praw Człowieka i Podstawowych Wolności, która notabene jest wpisana do Konstytucji Bośni i Hercegowiny (art. II) z zastrzeżeniem, że ma być stosowana bezpośrednio, a jej postanowienia

${ }^{52}$ S. Dizdarević, The Need to Change the Constitution of Bosnia and Herzegovina, „Südosteuropa Mitteilungen” 2005, Heft 4-5, s. 91-92

${ }^{53}$ Szerzej na ten temat zob. O.P. Richmond, J. Franks, Between Partition and Pluralism: the Bosnian Jigsaw and an „Ambivalent Peace”, „Southeast European and Black Sea Studies" 2009, no. 1-2. 
mają rangę ponadkonstytucyjną ${ }^{54}$. Po długim procesie sędziowie Trybunału w wyroku wydanym 22 grudnia 2009 r. uznali, że prawo wyborcze Bośni i Hercegowiny (w tym także odpowiednie artykuły ustawy zasadniczej) narusza Konwencję i wymaga zmiany ${ }^{55}$.

To postanowienie Trybunału może okazać się przełomowe dla procesu reform ustrojowych oraz oznaczać odrzucenie rozwiazań etnokratycznych i jednoczesne przyspieszenie realizacji „fazy Brukseli”. Jak zauważaja Damir Banović i Saša Gavrić, reforma konstytucji po grudniu 2009 r. jest konieczna z dwóch powodów - po pierwsze - należy uwzględnić w ustawach zasadniczych na poziomie centralnym i jednostek zarówno międzynarodowe, jak i regionalne dokumenty, odnoszace się do praw człowieka i obywatela, a przede wszystkim wspomnianą Konwencję, co oznacza usunięcie zapisów dyskryminujących ze względów etnicznych. Drugim powodem jest przyspieszenie implementacji acquis communautaire $\mathrm{w}$ procesie integrowania się $\mathrm{z}$ UE, co ma się przełożyć na zbudowanie państwa funkcjonalnego, ze sprawnie działającymi organami władzy i odpowiednimi procedurami demokratycznymi ${ }^{56}$.

Trzeba sobie jednak zdać sprawę z tego, że jakiekolwiek zmiany moga być wprowadzone dopiero na wiosnę 2011 r. Przez większą część 2010 r. trwały wprawdzie dyskusje dotyczace nowelizacji konstytucji - wszystkie zainteresowane strony zgadzaja się co do konieczności jej zmiany, uchwalono nawet osobny „Plan działania” - ale zabrakło już czasu przed październikowymi wyborami do podjęcia konkretnych kroków. Pewne różnice występują między partiami odnośnie do sposobu realizacji wyroku Trybunału w przypadku wyborów członków Prezydium. Proponowane są rozwiązania zwiększające liczbę członków do czterech lub zmianę sposobu wyboru na elekcję pośrednią (bez formalnego obostrzenia dotyczacego pochodzenia etnicznego) ${ }^{57}$. Jednak na ostateczne rozwiązania trzeba jeszcze poczekać co najmniej kilka miesięcy. Pozostaje mieć tylko nadzieję, że przeprowadzone na początku października 2010 r. wybory były ostatnimi, które opierały się na dyskryminujących przepisach.

Spis powszechny oraz podział majątku państwowego. Dla badaczy zajmujacych się problematyką Bośni i Hercegowiny niezmiennie zadziwiający musi być fakt, że po piętnastu latach od zakończenia wojny w odniesieniu do danych demograficznych wciąż trzeba posługiwać się informacjami z ostatniego

${ }^{54}$ Bośnia i Hercegowina ratyfikowała Konwencje 12 lipca 2002 r. - zob. Ć. Sadiković, Bosna i Hercegovina u europskim javnom putu, „Pregled” 2007, br. 4, s. 43.

${ }_{55}$ Pełny tekst postanowienia Trybunału w sprawie Sejdić $i$ Finci protiv Bosne $i$ Hercegovine (Aplikacje br. 27996/06 i 34836/06) jest dostępny na stronie internetowej http://www.coe.ba/web/dokumenti/presudaBIH.doc.

56 D. Banović, S. Gavrić, Ustavna reforma u Bosni i Hercegovini, „Politička misao” 2010 , br. 2 , s. 160

${ }^{57}$ Srbi protiv hrvatskog zahtjeva, Bošnjaci uvjetuju potporu, 10 III 2010, http://www.dnevnik.ba. 
spisu powszechnego, przeprowadzonego w kwietniu $1991 \mathrm{r}$. Bardziej istotne jest to, że dane uzyskane w jego trakcie nie zostały zweryfikowane, co dla części polityków, szczególnie serbskich, stanowi powód do podważania ówczesnych wyników ${ }^{58}$. Jest to o tyle zaskakujące, że kwestia etniczna i proporcji między poszczególnymi narodami stanowi jeden z głównych tematów dyskusji politycznej w Bośni i Hercegowinie. Bez przeprowadzenia spisu powszechnego nie ma też pełnych informacji na temat aktualnej liczby ludności państwa (wciąż podawane są jedynie szacunki!) oraz np. zmian migracyjnych wywołanych skutkami działań zbrojnych i związanych z nimi „czystek etnicznych”.

Stosunek do powyższego problemu zależy od przynależności narodowej. Zdecydowanymi zwolennikami przeprowadzenia spisu powszechnego są Serbowie, sprzeciwiają się natomiast Bośniacy. Kwestią sporna jest umieszczenie wśród zagadnień ankietowych pytań dotyczących wyznawanej religii i przynależności do grupy etnicznej. Bośniacy sprzeciwiają się umieszczeniu tych kwestii, gdyż uważaja, że ukazanie nowej struktury etniczno-religijnej uprawomocniłoby skutki „czystek etnicznych”. Natomiast dla Serbów sprawa ma inny wymiar spis powszechny ukazałby ich pełną dominację w Republice Serbskiej, co mogłoby podważyć konstytucyjna zasadę równouprawnienia wszystkich trzech narodów na obszarze całego państwa ${ }^{59}$. Chorwaci, podobnie jak Bośniacy, sceptycznie podchodzą do tak szczegółowych pytań, gdyż w wyniku licznej emigracji do Republiki Chorwacji ich liczba w Bośni i Hercegowinie znacząco się zmniejszyła.

Trudno sobie wyobrazić funkcjonowanie państwa bez posiadania choćby podstawowych danych o swoich obywatelach, dlatego przeprowadzenie spisu powszechnego jest konieczne. Do takiego wniosku doszli nawet główni rywale polityczni, gdyż podczas rozmów w Prudzie wstępnie uzgodniono, że zostanie on przeprowadzony w 2011 r. ${ }^{60}$ Niestety, nie implementowano zawartych tam postanowień. Pewien postęp zanotowano wiosna 2010 r., gdy projekt odpowiedniej ustawy przedłożyła specjalnie w tym celu powołana komisja. Zawarto w nim kompromisowe rozwiązanie - pytanie o religię i narodowość miało być fakultatywne (co zadowalało Bośniaków), natomiast na siedzibe instytucji analizujacej dane zaproponowano Wschodnie Sarajewo (Istočno Sarajevo), leżące w Republice Serbskiej. Dane uzyskane z tego spisu miały stać się podstawą nowych rozwiązań dopiero po ostatecznym powrocie do swoich domów wszystkich uchodźców ${ }^{61}$.

58 S. Jovičić Slavuj, Sličnosti i razlike: $R S$ i BiH od prije deset godina, „Nova srpska politička misao. Časopis za političku teoriju i društvena istraživanja”, 2 II 2008, http://www.nspm.rs.

${ }_{59}$ D. Spremo, Zašto Bošnjaci neće popis stanouništva 2011?, „Nova srpska politička misao. Časopis za političku teoriju i društvena istraživanja”, $3 \mathrm{~V}$ 2010, http://www.nspm.rs.

${ }^{60}$ Spis miał zawierać sporne pytania, ale do $2014 \mathrm{r}$. obowiązywać miały przy podziale stanowisk we wszystkich organach władzy proporcje z $1991 \mathrm{r}$.

${ }^{61} \mathrm{Na}$ pomolu dogovor o popisu pučanstva: Raspodjela vlasti po prijeratnom popisu i nakon 2014. godine?!, 19 V 2010, http://www.dnevnik.ba. 
Jednak sprzeczne interesy polityczne doprowadziły do wstrzymania prac nad projektem i szanse na przeprowadzenie spisu w planowanym czasie (wiosna 2011 r.) sa już tylko iluzoryczne. W takiej sytuacji parlament Republiki Serbskiej w czerwcu 2010 r. przyjął ustawę, dzięki której będzie możliwe przeprowadzenie spisu tylko na terytorium tej jednostki, jeżeli nie uda się go zrealizować na obszarze całego państwa ${ }^{62}$. Jeżeli rzeczywiście do tego dojdzie, grozi to kolejnym poważnym kryzysem politycznym w tym i tak głęboko podzielonym państwie.

Równie istotnym problemem stała się kwestia praw do posiadania własności odziedziczonej po czasach funkcjonowania Socjalistycznej Republiki Bośni i Hercegowiny. Od momentu rozpoczęcia procesu rozpadu Jugosławii organy władzy funkcjonujące na obszarze Bośni i Hercegowiny podjęły cały szereg decyzji odnośnie do własności publicznej, w tym licznych nieruchomości. Niejednokrotnie były one wzajemnie sprzeczne. Problemu nie rozwiązało także porozumienie z Dayton, a przyjęte w późniejszym okresie ustawy tylko częściowo uregulowały podział majątku państwowego między poszczególne poziomy władzy. Wobec braku woli porozumienia wśród miejscowych polityków, we wrześniu $2004 \mathrm{r}$. Komitet Sterujący PIC wezwał organy Bośni i Hercegowiny do „wypracowania trwałego porozumienia" w tej sprawie ${ }^{63}$.

Rada Ministrów powołała wprawdzie Komisję ds. majątku państwowego, która miała się zająć przeprowadzeniem spisu, ale jej funkcjonowanie było dalekie od ideału. Brak postępu zmusił Wysokiego Przedstawiciela do narzucenia w marcu 2005 r., na poziomie centralnym i jednostek, ustaw, które czasowo zabraniały dokonywania zmian w stosunku do praw własności. Nie spowodowało to jednak przyspieszenia prac przygotowujacych do przeprowadzenia spisu. W lipcu 2007 r. powołano nowy skład komisji, który okazał się równie skłócony jak poprzedni i niezdolny do przygotowania jakiegokolwiek projektu ustawy. Nie pomogły w tym zakresie nawet rozmowy liderów głównych partii opozycyjnych, przeprowadzone w grudniu 2008 r. w Prudzie. Dopiero kolejna interwencja Wysokiego Przedstawiciela, podjęta w sierpniu 2009 r., posunęła proces do przodu. Choć formalnie miała to być tylko „pomoc techniczna przy przeprowadzeniu spisu majątku państwowego i rewizji jego rezultatów”, faktycznie oznaczała przejęcie pełnej kontroli nad spisem przez $\mathrm{OHR}^{64}$. Tym samym, co można uznać za paradoks, Wysoki Przedstawiciel podjął się zadania, którego wypełnienie stanowi jeden z warunków likwidacji jego urzędu. bitno.

${ }^{62}$ Srpska će popisati stanouništvo iduće godine, ako BiH neće, 22 XI 2010, http://www.

${ }_{63}$ Popis držaune imovine u Bosni i Hercegovini izuršen pod pokroviteljstvom Ureda visokog predstavnika. Završni izvještaj, Decembar 2009, http://www.ohr.int.

${ }_{64}$ Visoki predstaunik pokréce Komisiju za popis držaune imovine, 12 IX 2009, http://www.ohr.int. 
Spis własności zakończył się w grudniu 2009 r. opublikowaniem raportu. Wynika z niego, że doliczono się 1 tys. jednostek majątku narodowego, z czego 21 znajduje się poza granicami Bośni i Hercegowiny. Około 30\% zostało zarejestrowanych jako należące do byłego Ministerstwa Obrony Socjalistycznej Federacyjnej Republiki Jugosławii, a dalsze 20\% stanowiło własność różnych socjalistycznych organizacji społeczno-politycznych ${ }^{65}$. Patrząc na te dane nie można zapomnieć, iż to dopiero początek właściwego, znacznie poważniejszego działania, czyli podziału majątku między różne poziomy władzy. Trudno przy tym być optymista, jeśli nawet najłatwiejsza czesść procesu okazała się za trudna dla lokalnych polityków i konieczna była interwencja czynnika zewnętrznego.

\section{Wnioski na przyszłość, czyli quo vadis, Bośnio i Hercegowino?}

Bośnia i Hercegowina w piętnaście lat po podpisaniu porozumienia kończącego wojnę bez wątpienia znajduje się na politycznym rozdrożu. Przestała być w pełni rządzona według „systemu daytońskiego”, który uległ przez ten czas w większym lub mniejszym stopniu modyfikacji, ale też nie jest jeszcze w „fazie Brukseli”, mimo stopniowej implementacji porozumień wskazywanych przez instytucje unijne. Co więcej, nie jest wcale pewne, który z wariantów rozwoju sytuacji będzie w rzeczywistości zrealizowany. Odrzucając na bok rozwiązania najbardziej pesymistyczne (choć wciąż realne), czyli rozpad państwa lub utrzymanie status quo i trwanie $\mathrm{w}$ tym niewydolnym systemie, można wskazać trzy możliwe scenariusze zmian polityczno-ustrojowych:

1) pełne zniesienie struktur przyjętych w Dayton, w tym likwidacja podziału państwa na Federację i Republikę oraz odrzucenie dominacji zasad etnokratycznych; przy takim modelu Bośnia i Hercegowina miałaby się stać państwem podzielonym na samodzielne, funkcjonalne pod względem gospodarczo-ekonomicznym regiony;

2) pełna centralizacja państwa i związana $\mathrm{z}$ tym głęboka reforma instytucjonalno-prawna;

3) przekształcenie Bośni i Hercegowiny w państwo złożone z trzech bądź czterech jednostek, zbudowanych na zasadzie symetrii między elementami etnicznymi i terytorialnymi ${ }^{66}$.

Jak uważa E. Šarčević, do realnej poprawy sytuacji w Bośni i Hercegowinie konieczne jest spełnienie następujących warunków:

65 Popis držaune imovine.

${ }^{66}$ Z. Pajić, Bosna i Hercegovina: državnost na raskrižju puteva, „Status” 2006, br. 9, s. 126 . 
- deinstytucjonalizacja rządów etnokratycznych wraz ze wspomagającymi je ideologiami funkcjonującymi w nauce i polityce;

- jasny podział kompetencji między poziom władz centralnych oraz jednostek jako punkt wyjścia do dalszych reform ustrojowych;

- czytelne powiązanie sposobu wyboru poszczególnych organów władzy i ich kompetencji (silna legitymizacja - szerokie kompetencje i na odwrót);

- prawa zbiorowe (kolektywne), które już podlegają i dalej będą podlegać specjalnej ochronie proceduralnej („ochrona żywotnych interesów narodu”), muszą zostać wcześniej dokładnie sprecyzowane i stanowić katalog zamknięty; musza ponadto obejmować taki sam zakres przedmiotowy w obu podmiotach;

- utrzymanie na poziomie centralnym parlamentu bikameralnego, ale zmiana charakteru izb na wzór klasycznych rozwiązań w państwach federalnych jedna izba reprezentowałaby wszystkich obywateli (suwerena), a druga - podmioty (jednostki);

- wybór sędziów Sądu Konstytucyjnego nie może być determinowany kryterium etnicznym ani miejscem zamieszkania ${ }^{67}$.

Jak z kolei uważa Sead Turčalo, kluczem do „dedaytonizacji”, czyli reformy niewydolnego „systemu daytońskiego”, jest działanie oparte na dwóch krokach. W pierwszym należy zerwać ten typ współpracy między przedstawicielami wspólnoty międzynarodowej, w tym OHR, oraz politykami bośniackimi, który opiera się na kontaktach pozainstytucjonalnych i nieoficjalnych, podważajacych legalnie obowiązujące procedury. Drugi krok wymaga przyznania przez wspólnotę międzynarodowa, że Bośnia i Hercegowina de facto nie jest państwem i że dotychczasowy porządek polityczno-ustrojowy nie jest $\mathrm{w}$ stanie zapewnić funkcjonalności. Takie podejście ze strony „samego kreatora państwa może stworzyć szansę dla budowy takiej wspólnoty politycznej, która posiadałaby to, czego obecna Bośnia i Hercegowina nie posiada - wertykalną i horyzontalną legitymizację" 68 .

Istotnym czynnikiem rzutujacym na przyszłość państwa jest opinia samych jego obywateli co do kierunku reform. Według badań opinii publicznej zaskakująca jest zgoda przedstawicieli wszystkich narodów konstytutywnych co do tego, że Bośnia i Hercegowina w obecnej formie nie ma szans na sprawne funkcjonowanie, natomiast opinie na temat pożądanych zmian są już $\mathrm{w}$ znacznym stopniu odmienne. Według Serbów najlepszym rozwiązaniem byłoby odłączenie się Republiki i zjednoczenie z Serbia - za taką opcja opowiada się prawie $81 \%$ badanych. Akceptowalne jest jeszcze przekształcenie Bośni i Hercegowiny w federację złożoną z trzech podmiotów (60\% poparcia). Dla Bośniaków opcja numer jeden jest państwo unitarne bez jednostek i kantonów, czyli silnie scentralizowane (82\%). Wśród Chorwatów najmilej widziane byłoby stworzenie

${ }^{67}$ E. Šarčević, Deytonski ustav: karakteristike i karakteristični..., s. 89-90.

${ }^{68}$ S. Turčalo, $d z$. cyt., s. 20. 
federacji składającej się z trzech podmiotów (72\%). Warto podkreślić w przypadku tego narodu istotna zmianę - opcja przyłączenia się do Chorwacji jest popierana przez mniej niż połowę mieszkańców ${ }^{69}$.

Analizując powyższe dane można mieć poważne wątpliwości co do przyszłości Bośni i Hercegowiny. Bardziej pozytywny wydźwięk mają wyniki badań porównujących zaufanie międzyetniczne w 2008 i pod koniec 2010 r. Według Instytutu Gallupa, przed dwoma laty tylko 48\% Serbów ufało Bośniakom i Chorwatom, obecnie $-67 \%$ ufa Chorwatom ${ }^{70}$, a 62\% Bośniakom. Połowa Bośniaków w 2008 r. miała pozytywne zdanie o członkach pozostałych narodów konstytutywnych, po dwóch latach ten odsetek wzrósł do 60\% (Chorwaci) i 59\% (Serbowie). Natomiast wśród Chorwatów większym zaufaniem cieszą się Serbowie (73\% wobec $72 \%)$ niż Bośniacy, wobec których sympatie zmalały $(63 \% \text { wobec } 67 \% \text { w } 2008 \text { r. })^{71}$.

Różnie mogą być traktowane dane dotyczące incydentów na tle etnicznym, których liczba w ostatnim okresie waha się. W 2006 r. odnotowano miesięcznie przeciętnie 9,26 incydentów, w następnym roku - 7,08, w 2008 - 9,16, w 2009 12,5 , ale już w pierwszym kwartale $2010 \mathrm{r}$. zanotowano znaczny spadek $-6,92^{72}$.

Próbując przewidzieć rozwój sytuacji w najbliższym okresie w Bośni i Hercegowinie, badacz staje przed niebagatelnym problemem. Widoczne sa bowiem zarówno sygnały pozytywne (jak chociażby opisany powyżej wzrost zaufania), jak i negatywne (np. dominacja wśród Serbów chęci przyłączenia się Serbii - i to wbrew sugestiom płynącym z Belgradu). Jednak można zaryzykować stwierdzenie, że najgorszy okres to państwo ma już za sobą i po piętnastu latach istnienia (celowo nie zostało użyte słowo „funkcjonowania”) nie grozi mu już rozpad, mimo ostrzeżeń płynących z Republiki Serbskiej.

Co zatem Bośni i Hercegowinie pozostaje? Wydaje się, że przyjęty kierunek zmian „od Dayton do Brukseli” jest jedynym sensownym rozwiązaniem. W obliczu sprzeczności wewnętrznych, braku wspólnej wizji państwa i pełnej chęci do kooperacji między narodami konstytutywnymi, Bośnia i Hercegowina ma szansę przetrwać tylko wtedy, kiedy stanie się elementem większego, ponadpaństwowego organizmu - Unii Europejskiej. Bruksela może w tym przypadku odegrać pozytywną rolę spajająca i integrująca ${ }^{73}$, podobną - przy zachowaniu odpowied-

${ }^{69}$ Pat u BiH: Srbi za odcjepljenje (81\%), Hrvati za treći entitet (72\%), Bošnjaci za unitarnu BiH (82\%), 30 III 2010, http://www.dnevnik.ba.

${ }^{70}$ Jako przykład zaskakujacego wzrostu sympatii dla Chorwatów może posłużyć przyznanie przez największy dziennik w Republice Serbskiej „Nezavisne novine” tytułu „Osobowości 2010 Roku” dla prezydenta Chorwacji Ivo Josipovicia - zob. Ivo Josipović ličnost godine, 6 XII 2010, http://www.nezavisne.com.

${ }^{71}$ Dane za: D. Šajinović, Narodi u BiH sve više vjeruju jedni drugima, 21 XII 2010, http://www.nezavisne.com.

${ }^{72}$ Federation of Bosnia and Herzegovina..., s. 13.

${ }^{73}$ Choć po uznaniu niepodległości Kosowa przez większość krajów unijnych i naruszeniu tym samym status quo na Bałkanach można mieć co do tego pewne watpliwości. Jednak 
nich proporcji i dystansu - do tej, którą pełnili kiedyś Osmanowie lub Habsburgowie ${ }^{74}$. Pewne szanse daje postępujący proces ratyfikowania SAA przez kolejne państwa unijne oraz zniesienie obowiązku wizowego od połowy grudnia $2010 \mathrm{r}$. Natomiast Bośnia i Hercegowina pozostawiona na uboczu, otoczona - zakładając optymistycznie - państwami członkowskimi UE, prawdopodobnie rozpadłaby się na mniejsze byty polityczne, ciążące ku sasiadom (Herceg-Bośnia i Republika Serbska) lub będące siedzibami skrajnych ruchów islamistycznych.

trzeba podkreślić, że wśród polityków unijnych problematyka Bośni i Hercegowiny zajmuje istotne miejsce, a misja EU w Sarajewie należy do największych spośród wszystkich istniejacych - w 2009 r. liczyła 100 dyplomatów (większe były w tym czasie tylko w Moskwie i Tokio) - zob. R. Belloni, $d z$. cyt., s. 371.

${ }_{74}$ E. Redžić, Aggression, Conspiracy and Division: the Historical End of the Bosnia and Herzegovina State, „Dialogue International Edition” 1998, no. 9-10, s. 36. 